\title{
توليد زردك
}
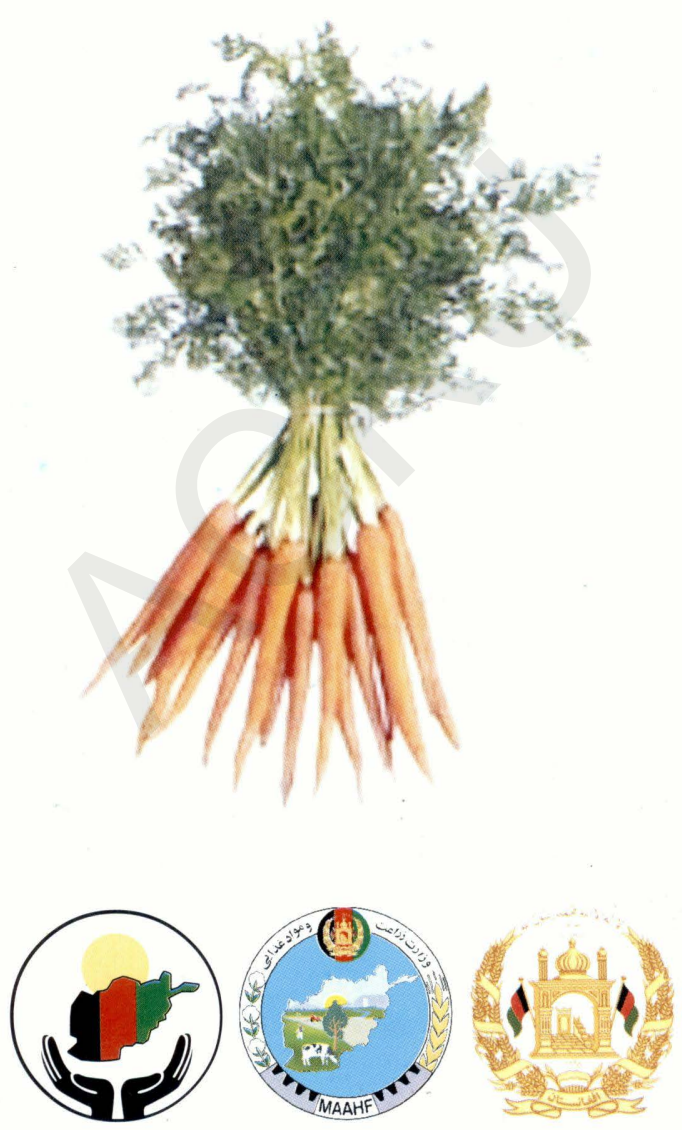

به جاى تخم حرام، حلال كثت كنيد 
زردى از جمله سبزيجات مهم دنيا و افغانستان بشمار ميرود، زردى داراى مواد غذايى خوب براى انسانها بوده، و يك نبات دوساله ميباشد كه به قسم خام و يخته از آن استفاده بعمل ميآيد و منبع خوب ويتامينهاى اى، بى، ايى، سى و عناصر اهن، كلسيه، مس، فاسفورس و كروتين ميباشد كه براى صحت و سلامتى انسانما مفيد واز مرض شب كورى جلو گرى مينمايد. زردى به رنگهاى زرد، نارنجى، سفيد وغيره بيدا ميشود.

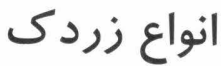

زردى نيز داراى انواع و اقسام مختلف ميباشد، و سعى بعمل ايد كه نوع زردك كشت گردد، كه تقاضا و ميل مستهلكين و ماركيت را مرفوع ساخته بتواند. برعلاوه انواع محلى يك تعداد انواع اصلاح شده مثل جنتانى، ايرانى وغيره، نيز در افغانستان بذر

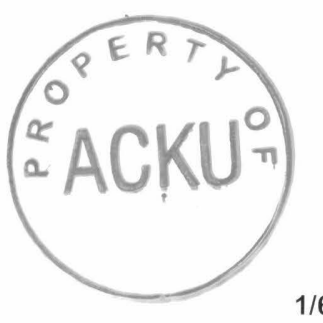

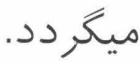


معلومات مختصر در مورد برورش زردك

وقت كشت و خاك

زردى باوجوديكه يك نبات موسم سرد است، ليكن براى نموى بهتر به خاك گرم ضرورت دارد. زردك در مناطق گرمسير در ماه ميزان و در مناطق سردسير از ها حوت الى ها حمل كشت ميشود. خاك بايد نرم وحاصلخيز باشد. زمين جندين مراتبه قلبه و ماله شود كه خوب هموار گردد، عمق قلبه ه r سانتى متر باشد، بعد آ بشكل جويه و يشته و يا هم بشكل خطى امده گردد. زردى لرى در خاكهاى ريگى لوم و نرم خوب نمو ميكند. مقدار تخم

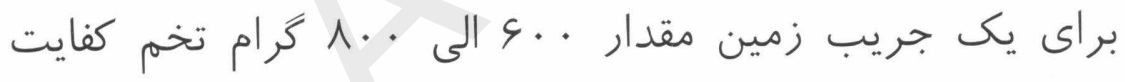
ميكند، تخم بايد سالم و از منابع مطمين بدست امده، تخم كهنه نه باشد. تخم زردى به عمق ا الى r سانتى متر بذر گردد.

طريقه كشت زردى - م

زمين وقتيكه به شكل جويجه و يشته و يا هم به شكل خطى امده كرديد، كه فاصله بين جويجها VD سانتى متر و فاصله بين دو AFGHANISTAN CENTRE AT KABUL UNIVERSTY

$2 / 6$

3 ACKU 000137066 


\section{معلومات مختصر در مورد يرورش زردك}

قطار • ץ سانتى متر و فاصله بين دو نبات س الى ه سانتى در نظر گرفته شود. جون تخم زردى بسيار كوجى و ميده ميباشد، در وقت ياش دادن، ريخ ميده به اندازه تخم، با تخم ان مخلوط گُدد، تا از ضايعات تخم جلوگيرى بعمل ايد.

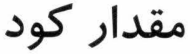

براى اينكه حاصلات بلند و با كيفيت از مزرعه زردك بدست | ورده باشيم، لازم است مقدار معين انبار حيوانى خوب يوسيده و خشك شده را كه براى يك جريب زمين سفارش شده، قبل از كشت در خاك علاوه گردد. لازم به تذكر است، كه مقدار

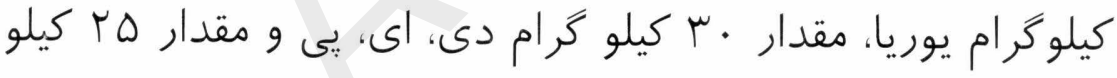
گرام كود يوتاشيم دار در يك جريب زمين استعمال گردد. تمام كود دى،اى،يى، كود يوتاشيم دار و نصف كود يوريا در وقت بذر و متباقى نصف كود يوريا در وقت يكه كردن استعمال گردد.

\section{خيشاوه كردن}

براى اينكه حاصلات قناعت بخش از ساحه كشت شده زردى بدست امده باشد، لازم است گياه هرزه وقتآ فوقتآ از مزرعه 
معلومات مختصر در مورد يرورش زردى

زردى خيشاوه و پاك گردد. كنترول گياه هرزه در طول موسم

نمو r الى ب مرتبه صورت ميخرد. خيشاوه بقسم سطحى صورت

گيرد، تا ريشه هاى زردى متضرر نشوند.

يكه كردن زردى

حينيكه نبات زردى به بلندى ه سانتى متر نمو كرد ، مزرعه زردى يكه شود، تا بته ها در فاصله معين به نمو مناسب خود ادامه دهند. در غير آن اگر در يك ساحه معين تعداد بته ها زياد باشد، سبب ضعيف شدن بته هاى زردى گرديده، حاصلات قناعت بخش از مزرعه زردك بدست آمده نميتواند.

آبيارى

زردى در مقابل خشكى زياد حساسيت دارد. اگر كرد زردى

قبل از كشت رطوبت كافى داشته نه باشد، زمين بايد وتر گردد.

اگر مزرعه زردك در وقت كشت خشك باشد، در آن صورت روز بعد از كشت آبيارى صورت گيرد، تا تخم زردك به درستى سبز شده بتواند، بعدآ نظر به ضرورت بعد از هر م الى . ا روز

4/6 
معلومات مختصر در مورد برورش زردى

مزرعه زردك ابيارى گردد. كمى آب سبب پائين آمدن حاصل

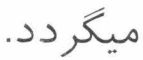

جمع آورى حاصلات

جمع آورى حاصلات در بعضى ممالك توسط ماشين صورت ميگرد، ولى در افغانستان توسط دست و وسايل محلى زراعتى جمع آورى ميكردد. در بعضى ممالك خارجى اكثرآ قسمت بالايى زردك را دور ميكند و بعدآ شسته شده و درجه بندى

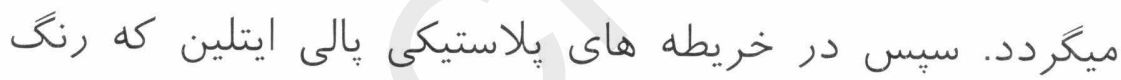
آنها شفاف ميباشد، انداخته ميشود. خريطه هاى يلاستيكى از كم شدن وزن ريشه جلوگيرى نموده و در ذخيره خانه ها عمر زردى را طولانى ميسازد. خريطه يلاستيكى داراى سراخها ميباشد تا مزه و طعم زرد كها ضايع نشود.

زخيره ونَّهدارى زردك در درجه حرارت صفر كه رطوبت نسبتى ب9 الى 91 باشد،خوب نكمدارى ميشود. رطوبت نسبتى كم سبب يزز مرده شدن زردك ميگردد. براى ذخيره كردن مدت زياد قسمت

$5 / 6$ 
بالاى زردى دور گردد. زردكهاى كه ذخيره ميشود، بايد زخمى و مريض نباشد.خوشبختانه مشكلات قابل ملاحظه امراض و افات زردك در افغانستان موجود نميباشد.

علايم

اين ششره از شيره برى هاى نبات مز كورتغذيه نموده ونبات را ضعيف ساخته و باعث تقليل حاصل در نبات ميخردد.

Aphids شيشك زردى

\section{كنتر ول}

مقدار يكنيم سى سى تيودان در يكى ليتر آب حل و دواياشى كردد. - n

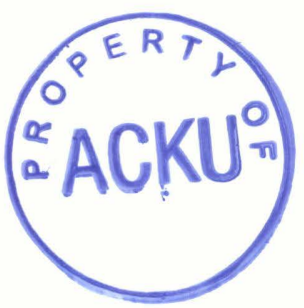




\section{ACKU}

$B$

$5 \cdot 142$

$M \triangle A$

13706

cop-2
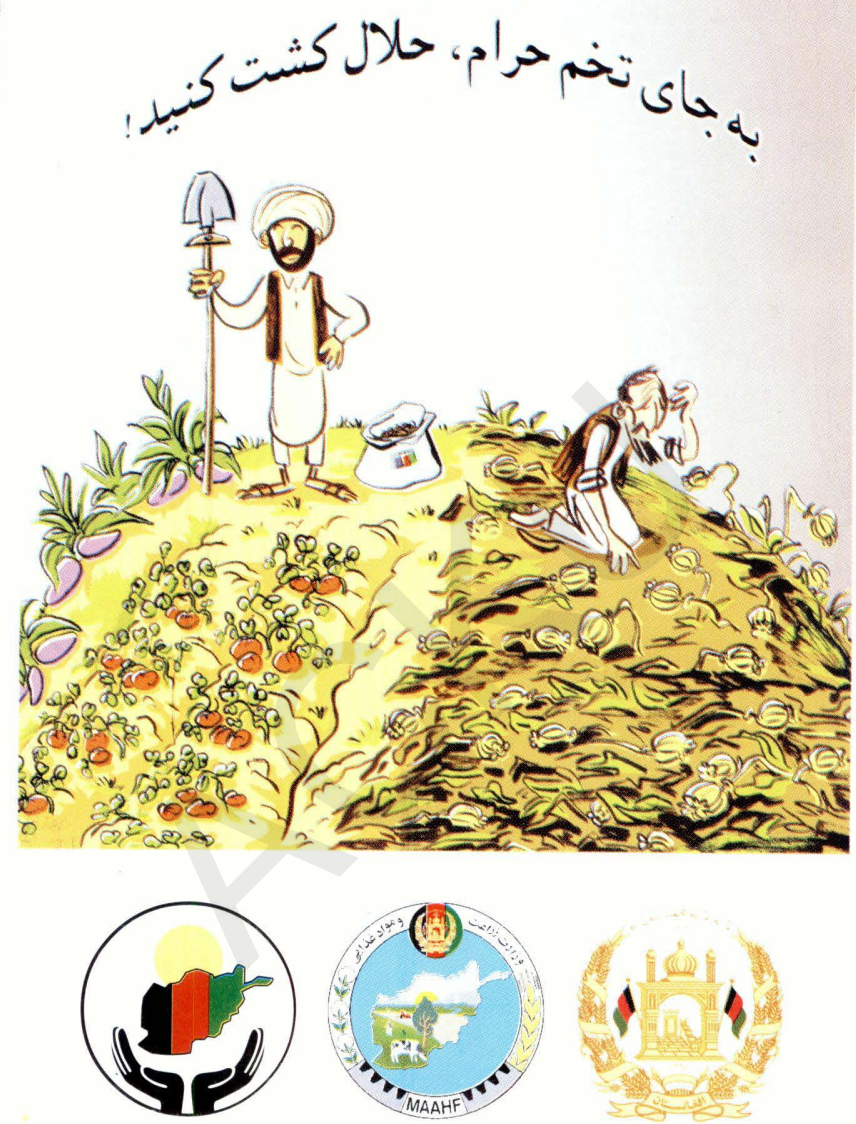

وزارتهاى زراعت و مبارزه عليه مواد مخدر با هم يكجا كار ميكنند تا كمكى براى دهاقينى كه

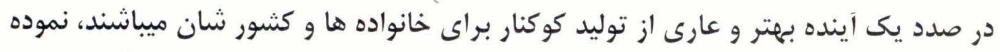

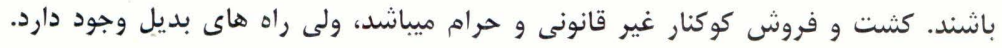

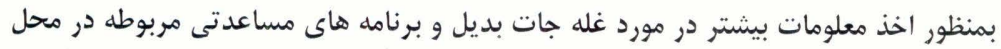
تان، به رياست زراعت ولايت مربوطه تان مراجعه نماييد.

تحت نظر رياست نشرات وزارت زراعت، مالدارى و مواد غذايى 